\title{
An Introduction to Quintus Smyrnaeus' Posthomerica
}

\author{
MANUEl BAUMBACH, SiLVIO BÄR
}

\section{Quintus and his Time}

\subsection{Name and Dating}

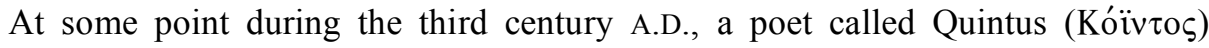
wrote an epic poem in a strongly Homerising hexameter style in which he renarrated the final events of the Trojan War, beginning (without a proem) where Homer's Iliad ends, and recounting all the post-Iliadic events up to the sack of Troy and the nostos of the surviving Greek heroes. Accordingly, the poem was

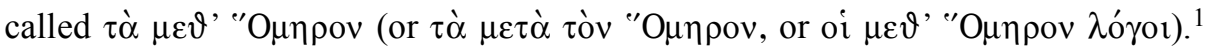
Thus, it apparently competed with the texts of the Epic Cycle which told the same stories. However, we do not know with certainty whether these texts were still accessible or already (partially) lost in the third century A.D. ${ }^{2}$ If they were lost, Quintus' Posthomerica may have had the primary function of fulfilling the 'public need' for an epic poem to bridge the gap between the Iliad and the Odyssey; ${ }^{3}$ on the other hand, even if the Epic Cycle was still in circulation at that time, Quintus could nevertheless have composed his 'own version'.

As to his biography, we know virtually nothing about our poet. The name Kóivi os may or may not point to a Roman origin. In the first case, we might consider a possible parallel in Lucian of Samosata, who was of non-Greek provenance and whose native language was not Greek, but who was able to acquire Greek to such an extent that he wrote literature of the highest quality in this idiom. We may, however, view Quintus as one of the many Greeks who are known only by their Latin praenomen - a phenomenon which is characteristic not

1 On the title, cf. Köchly (1850) 1, Vian (1963) VII-VIII, Appel (1994c) 2-4.

2 This is a moot point indeed; cf. Gärtner (2005) $28 \mathrm{n}$. 10 for a survey of the differing scholarly views. However, we should perhaps not solely think in absolute terms of either 'still accessible' or 'lost' - the texts of the Cycle (which was not one single 'piece of text', after all) may have been (partially) lost at a certain time and in a certain place, but at the same time still (partially) available somewhere else.

3 On other potential Wirkungsabsichten of the poem, cf. below, ch. 1.2. 
least of the social upper class during the imperial period. ${ }^{4}$ The provenance 'from Smyrna', then, is probably not autobiographical, but a mere metapoetic allusion by which Quintus establishes himself as a second Homer, since the piece of information is derived from the only in-text proem (Binnenproömium) of the Posthomerica (Q.S. 12,306-313) where the epic 'I' recounts that he has been divinely inspired by the Muses whilst tending sheep "in the land of Smyrna"

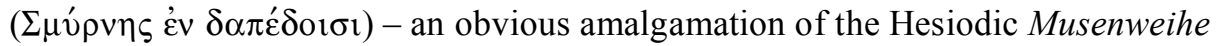
and the common ancient notion of Smyrna as Homer's birthplace. ${ }^{5}$

How, then, are we to date Quintus' epic poem? ${ }^{6}$ Lorenz Rhodomann, the first critical editor and translator of the Posthomerica (cf. below, ch. 2.2.), 'felt' that from a linguistic point of view, Quintus had to be 'late'. Furthermore, he rightly pointed to a simile in Q.S. 6.531-537 which describes deadly fights between wild beasts and slaves, organised by the "’ $\nu \alpha \kappa \tau \varepsilon \varsigma$ in order to entertain the people, as well as to Kalchas' prophecy in Q.S. 13.336-341 where Aeneas' destiny as the future founder of Rome is foretold, and concluded that, as a consequence, Quintus must have been living "sub Monarchia Romana". 7 Then, two hundred years later, Gottfried Hermann convincingly demonstrated that, judging by his vocabulary and syntax, Quintus was likely to belong to the imperial period, but because of his metre, was probably earlier than Nonnos of Panopolis (mid- $5^{\text {th }}$ cent. A.D.), ${ }^{8}$ as he seems not to be influenced by the latter's metrical 'reforms'. 9 Since there is, in addition to this, sufficient evidence to argue that Nonnos knew and 'imitated' - or at least in some ways responded to - the Posthomerica, ${ }^{10}$ Quintus can be firmly established as chronologically prior to Nonnos. Furthermore, it has been argued that Triphiodoros, the author of the 'epyllion' 'I $\lambda$ iov $\alpha$ ' $\lambda \omega \sigma ı \varsigma$, was intertextually indebted to Quintus. ${ }^{11}$ This, then, would provide a relatively secure terminus ante

4 Cf. Vian (1963) VIII, Rizakis (1996), James / Lee (2000) 5.

5 On this topic, cf. the contribution of S. Bär in this volume. As far as we know, Quintus is first called o $\Sigma \mu v \rho v \alpha i o \varsigma$ by John Tzetzes; cf. below, ch. 2.1., with n. 69 .

6 On Quintus' dating, cf. most recently James / Lee (2000) 4-9, James (2004) XVII-XXI, Gärtner (2005) 23-26.

7 Rhodomann (1604) praef. (non paginated).

8 On the dating of Nonnos, cf. Vian (1976) IX-XVIII, who narrows the Dionysiaca down to between 450 and 470 A.D. (cf. XVII).

9 Hermann (1805) passim. However, James / Lee (2000) 5 rightly object that "[t]his consideration alone is insufficient to establish relative chronology". Moreover, lack of influence (i.e., more precisely, no traces of positive evidence) must not necessarily account for lack of acquaintance - theoretically, Quintus may well have been familiar with Nonnos' 'reforms', but might have deliberately avoided them.

10 On Quintus and Nonnos, cf. the contributions of F. Hadjittofi and R. Shorrock in this volume.

11 Cf. James / Lee (2000) 5 and James (2004) XIX, disputed by Gärtner (2005) 25 ("gibt es kaum stichhaltige Argumente"). However, the scholars who believe that Quintus is prior to Triphiodoros are in a majority. For a survey of the opinions see Dubielzig (1996) 11 and Gärtner (2005) 25 n. 16. 
quem, as Triphiodoros can, on the evidence of a papyrus fragment (POxy. 2946), be dated no later than the very early fourth century A.D. ${ }^{12}$ On the other hand, there is a terminus post quem as well: Quintus is intertextually indebted to Oppian's Halieutica ${ }^{13}$ which is dedicated to Marcus Aurelius and his son Commodus who jointly reigned between 176 and 180 A.D.; therefore the Halieutica must have been composed during this very period of time, which, in turn, means that the Posthomerica must be at least later than this.

Many other arguments, then, have been put forward in order to date Quintus and his poem more precisely. They are as numerous as they are unconvincing. The two similes that Rhodomann recognised as indicative of a date for Quintus in the imperial period (cf. above) were 'exploited' further. For one thing, one felt tempted to see 325 A.D. as a terminus ante quem because gladiator fights were interdicted after that time in the eastern part of the empire but are alluded to in Q.S. 6.531-537. ${ }^{14}$ Likewise, 330 A.D. was regarded as a terminus ante quem because Constantinople had been established as the new seat of government at that point, but Quintus seems to regard Rome as the empire's capital according to Kalchas' prophecy about Aeneas' destiny as the future founder of Rome (Q.S. 13.336-341). ${ }^{15}$ Similarly, Cantilena suggested that the Posthomerica was unlikely to have been composed even after 248 A.D. because of Rome's millennial celebrations, held in accordance with the 'Virgilian doctrine' that Romulus and Remus, not Aeneas, had founded Rome, whereas according to Quintus, it was Aeneas

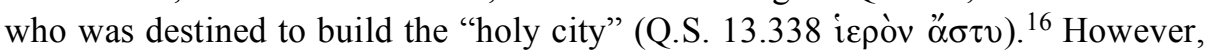
none of these arguments is in any way compelling: similes do not necessarily reflect contemporary politics, and moreover, gladiator fights are likely to still have been part of the collective / cultural memory even if they were not carried out any more. Similarly, Quintus may well have been departing from the 'official version' about the capital and its founders ${ }^{17}$ - one may even go so far as to interpret Kalchas' prophecy as a deliberate rejection of the 'official Virgilian-Roman version' on a metapoetic level. ${ }^{18}$

12 POxy. 2946 was published by Rea (1972); cf. also Dubielzig (1996) 9-10 (with further discussion and bibliography), who narrows down Triphiodoros' dating to no later than the $3^{\text {rd }}$ cent. A.D. ("kann nicht später als im 3. Jh. gewirkt haben", 10).

13 On Quintus and Oppian, cf. the contribution of E. Kneebone in this volume.

14 Cf. Tychsen (1807) XXX-XXXI.

15 Cf. Vian (1963) VIII-IX, James / Lee (2000) 5, James (2004) XIX.

16 Cantilena (2001) 55-56.

17 Rome as the capital of the empire does remain a literary topos after 330 A.D.; cf. Tychsen (1807) XXX and Gärtner (2005) 24.

18 Cf. Vian (1963) VIII-IX: "Quintus se sépare de la doctrine devenue officielle depuis Virgile : il attribue à Énée non la fondation de Lavinium, mais celle de Rome elle-même, conformément à une tradition hellénique [...]" On the hypothesis that Quintus may be deliberately 'unwriting' 
In addition to this, Cantilena - in order to strengthen his thesis pinning down Quintus to the early third century A.D. - developed the idea that the Posthomerica could not have been composed after 250 A.D. because after this time, the cultural centres of the Second Sophistic shifted from Anatolia to cities such as Constantinople, Antiochia, and Alexandria. ${ }^{19}$ However, this has to be rejected as unduly over-generalised; above all, the authenticity of Smyrna as Quintus' place of origin is not sound (cf. above). Likewise, the objection that Quintus must not be dated to the early third century A.D. because he is not mentioned in Philostratus' Lives of the Sophists (Vitae Sophistarum), which were composed in the late 230's and in which the cultural life of Smyrna takes pride of place, ${ }^{20}$ may be discounted on the same grounds. Moreover, Philostratus certainly did not aim for completeness; in fact, Scopelianus is the only sophist named by him who composed epic poetry as well, ${ }^{21}$ and neither of the two Oppians is mentioned. ${ }^{22}$ Thus, from this point of view, there is no reason to disbelieve that the Posthomerica could (theoretically) have been composed before the publication of the Vitae Sophistarum.

Finally, a dating to the middle of the fourth century A.D. was proposed by John Dillon. ${ }^{23} \mathrm{He}$ was able to point out striking parallels between Quintus' pair of women's speeches (Q.S. 1.403-476) and a treatise by the Neoplatonist Theodoros of Asine (c. 275-360 A.D.) about the equality of male and female virtue. Interesting though these parallels are, Dillon's assumption that Quintus composed his pair of speeches under the influence of this treatise is unconvincing. Firstly, it is methodologically problematic to build up a dating on one single parallel between two such very different genres of text. Secondly, it seems much more promising not to see the two pieces of text as directly dependent on each other, but rather as reflections of contemporary discourses about the same topic in two different genres. Thirdly, if a direct dependency is to be postulated at all costs, one ought to consider the possibility that the influence might also have operated the other way round, i.e. that Theodoros may as well have been inspired by Quintus' unortho$\operatorname{dox} \mu \varepsilon \lambda \varepsilon \dot{\tau} \tau$.

However, apart from these inconclusive pieces of evidence, some further potential proof of dating has been seen in the so-called óp $\alpha \sigma 1 \varsigma \Delta \omega \rho \circ \vartheta$ ćov (visio

Virgil's Aeneid, cf. below, ch. 2.2., n. 97. On Quintus and his 'Roman politics', cf. the contribution of F. Hadjittofi in this volume.

19 Cantilena (2001) 54-55.

20 Cf. James / Lee (2000) 6 (however cautiously): "A hazardous argumentum ex silentio for a rather later terminus post quem is the fact that $\mathrm{Q}$. is not mentioned in a work that is remarkable for the richness of its information on the literary circles of Smyrna, Philostratus' Lives of the Sophists [...]"

21 Philostr. VS 514-521.

22 Nor is the second-century sophist Lucian of Samosata mentioned.

23 Dillon (1995) (on the dating see 34). 
Dorothei). This is a text, fragmentarily preserved on a codex (PBodm. 29) which is roughly datable to the late forth or early fifth century A.D., ${ }^{24}$ in which we recognise (as far as the substantially defective state of the text reveals) the record of a Christian's vision (be it autobiographical or fictional), recounted by a narrative 'I' in 343 Homerising hexameters. It ends with the following sphragis: $\tau \varepsilon$ ' $\lambda \circ \varsigma$

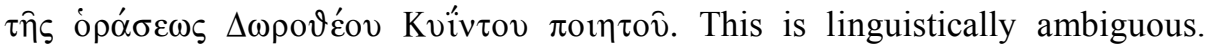
Theoretically, it can mean either "this is the end of the vision of Dorotheos, son of Quintus the poet" or "this is the end of the vision of Dorotheos Quintus the poet". In any case, as there are no other ancient records about a poet of this name, it seems reasonable to associate this Kóïv os with 'our' poet. In the first case, we would be faced with a son of Quintus called Dorotheos; in the second case, however, we would have to assume that Quintus' full name was actually Dorotheos Quintus and that he had written a pagan as well as a Christian poem. The latter hypothesis is tempting inasfar as it would provide a striking parallel to Nonnos and other 'semi-pagan, semi-Christian' authors, and an instructive example for the phenomenon of the amalgamation of paganism and Christianity in the later imperial period in general. ${ }^{25}$ However, the assumption has to be rejected because in verse 300 there is another nominatim self-reference in which the epic

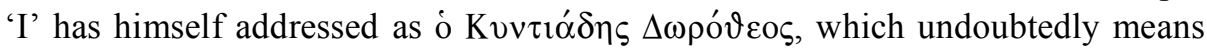
"Dorotheos, the son of Quintus". ${ }^{26}$ Furthermore, it has to be acknowledged that the visio Dorothei shows a fair number of severe deficiencies in its language and versification (for example, there are numerous cases of shortened $-\eta$ - in the middle of a word, which reveals influence from spoken language); ${ }^{27}$ therefore it seems unlikely that its author and the 'flawless' composer of the Posthomerica

24 Editions: Hurst / Reverdin / Rudhardt (1984), on which cf. also the lengthy reviews by Fantuzzi (1985) and Livrea (1986), and Kessels / van der Horst (1987). On the dating of the codex (nota bene, not necessarily the age of the text it contains), cf. Kasser / Cavallo (1984) ("le Codex des Visions a été écrit au début du V $V^{\mathrm{e}}$ siècle", 117), Kasser / Cavallo / Van Haelst (1991) ("de la seconde moitié du IV ${ }^{\mathrm{e}}$ siècle", 124).

25 Vian enthusiastically took to this possibility long before the first edition of the codex, cf. $i d$. (1976) XV n. 1: "Aux auteurs mi-païens mi-chrétiens [...] il faut maintenant ajouter Quintus de Smyrne dont un papyrus inédit a révélé qu'il avait écrit un poème chrétien après la Suite d'Homère [...]" However, having examined the published text and encountered its linguistic and prosodic deficiencies, he radically changed his mind and denied any relation between the authors of the two poems at all (cf. our n. 28).

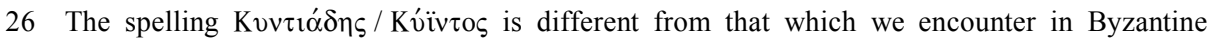
times, when the name is regularly spelt Köïv $\tau$ o (cf. below, ch. 2.1., with n. 70). However, there is no reason to see a problem in this difference, as both spellings are but ways of representing the Latin semi-vowel $/ u /$; cf. Tychsen (1807) XXIII.

27 On the linguistic and prosodic pecularities of the visio, cf. Hurst / Reverdin / Rudhardt (1984) 36-42 ("un poète qui a lu beaucoup de poésie épique, mais qui ne pousse pas jusqu'aux raffinements d'un Quintus de Smyrne ou d'un Nonnos", 42), Vian (1985), Rossi (2002). 
should be one and the same person. ${ }^{28}$ The former hypothesis, though, does not seem wholly improbable, especially as there are indeed certain similarities between the linguistic idiosyncrasies of the Posthomerica and the visio ${ }^{29}$ - which does not, of course, give proof of, but may at least neatly fit, a father-son-relation.

The first editors of the visio, then, were quick off the mark in identifying this Dorotheos. In book 7 of his Historia Ecclesiastica, Eusebius of Caesarea (c. 260340 A.D.) mentions an otherwise unknown "Dorotheos, ordained for priesthood at

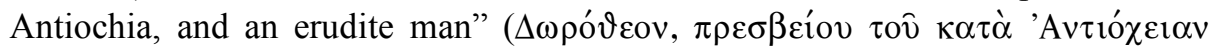

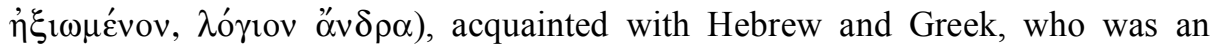

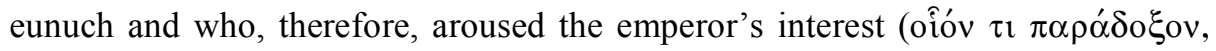
"as he considered this something very special"), with the result that he was

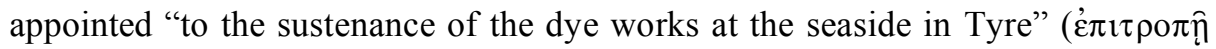

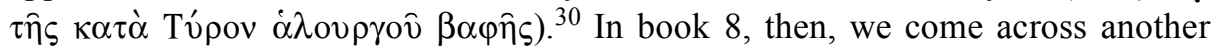
man of the same name. He also belonged to the court staff and was a Christian too, and he died the death of a martyr under Diocletian's persecutions. ${ }^{31}$ As a consequence, Hurst / Reverdin / Rudhardt suggested that these two Dorotheoi were one and the same person and likewise identical with the author of the visio. ${ }^{32}$ Therefore, as Diocletian's persecutions had begun towards the very end of the 290's, one was to assume that Dorotheos' father, Quintus, had been active as a poet at some point during the second half of the third century A.D. ${ }^{33}$

However, tempting and seemingly fitting though both these identifications seem at first sight, they do not rest on a firm enough basis. Firstly, the identity of Eusebius' two Dorotheoi is possible, but cannot be regarded as unquestionably

28 However, the deficiencies of the visio can, of course, in no way be taken as an indication that Quintus may not have been Dorotheos' father, as Vian (1985) 48 suggests: "[J]'ai peine à croire qu'il soit le fils de l'auteur de la Suite d'Homère." Likewise Livrea (1986) 688: "Sul piano linguistico, gli stupefacenti volgarismi prosodici, morfologici, sintattici e lessicali, mentre escludono che Doroteo sia il figlio di Quinto Smirneo [...]"

29 Cf., e.g., James / Lee (2000) 8-9. The same holds true for the hexameter poem Прò 'А $\beta \rho \alpha \alpha \alpha \mu$, which follows the visio on PBodm. 29 and is also ascribed to Dorotheos; cf. Livrea (1994).

30 Eus. Hist. Eccl. 7.32.2-3.

31 Eus. Hist. Eccl. 8.1.4. Apparently, this Dorotheos was some kind of a leader figure among the Christian court servants and therefore acquired some reputation, as Eusebius calls him oios

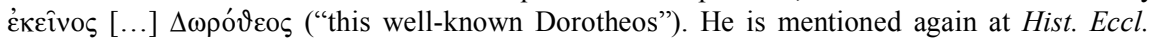
8.6.1.

32 Hurst / Reverdin / Rudhardt (1984) 47-49.

33 Cf. Hurst / Reverdin / Rudhardt (1984) 48: "Père d'un homme qui fut prêtre vers 290 et mourut martyr sous Dioclétien, Quintus de Smyrne aurait parfaitement pu vivre vers le milieu du III $^{\mathrm{e}}$ siècle [...]" - James (2004) XXI: "The son's career can be dated precisely by his wholly convincing identification with a Dorotheos mentioned several times in Eusebios' Ecclesiastical History [...] Accordingly the activity of Quintus can be securely dated in the second half of the third century A.D." The identity of the two Eusebian Dorotheoi is here taken for granted. 
proven. ${ }^{34}$ Secondly, 'Dorotheos' is too common a name in this period; therefore the identification of two (or rather three) persons carrying this name simply on the basis that they were (seemingly) all Christians and martyrs seems too far-fetched. Thirdly, it is astonishing that if there was indeed but one Dorotheos, Eusebius does not mention his poet-father (especially as he does refer to the first Dorotheos' education). Finally, it has to be taken into account that neither the content nor the narrator's name of the visio need necessarily be taken at facevalue, since the text represents, after all, a literary work of art. ${ }^{35}$ Hence, it is surprising that in spite of everything, the identification of Eusebius' Dorotheos / -oi with the author of the visio - and therefore also the dating of Quintus' Posthomerica to the second half of the third century A.D. - has virtually become communis opinio. ${ }^{36}$

All things considered, we may well acknowledge that "there is some probability in the thesis that Dorotheus is the (Christian) son of the (pagan?) poet Quintus Smyrnaeus", 37 but we have to conclude that the former cannot be securely identified and dated. On the other hand, it may also be suggested that Dorotheos might, for example, just as well have been Quintus' grandson

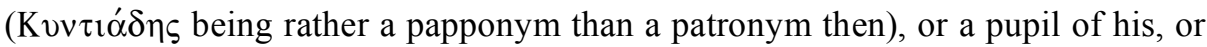
simply an educated Greek who inscribed himself into Quintus' 'traditionalist school' which followed a strongly Homerising / archaising style of epic. ${ }^{38}$ Therefore, it appears that as to Quintus' dating, the visio Dorothei provides no more than a terminus ante quem by the date of its physical codex (PBodm. 29), i.e. approximately 400 A.D.

To sum up: of all the pieces of evidence that have been put forward in order to date Quintus' Posthomerica, only the following seem to rest on a (relatively) firm basis: terminus post quem 'Quintus > Oppian (i.e. post 180 A.D.)'; termini ante quos 'Quintus < Nonnos (i.e. ante 450 A.D.)'; 'Quintus < PBodm. 29 (i.e. ante 400 A.D.)'; 'Quintus < Triphiodoros (i.e. ante 300 A.D.)'. All the remaining arguments, however, have to be challenged as either highly subjective or wholly unconvincing, or both. Therefore, it seems reasonable to date Quintus and his

34 They feature as two separate figures in the glossarium of Williamson / Louth (1989).

35 It may even be argued that 'Dorotheos' as the name of the narrative 'I' might be a meaningful name (sprechender Name) which is not necessarily identical with the author's real name.

36 Cf. Fantuzzi (1985) 186-187, Kessels/van der Horst (1987) 15-16, James / Lee (2000) 9, Schmiel / Garstadt (2000), James (2004) XXI, Cuypers (2005) 606.

37 Kessels / van der Horst (1987) 317.

38 Cf. Cuypers (2005) 606: "The case for the identification of Dorotheus' father with the author of the Posthomerica largely rests on verbal similarities that cumulatively present a reasonable argument for at least dependency from Q." - Cf. also below, ch. 1.2., for a possible way of understanding Dorotheos in the context of Quintus' place within the Second Sophistic. 
Posthomerica to the third century A.D., that is, to the approximate period between 200 and 300 A.D., without further specification.

\subsection{The Cultural Background of the Second Sophistic}

Due to the problems of dating the Posthomerica and the complete lack of information about the author as a historical figure as well as the missing reception of the epic in Antiquity, we can only speculate about the cultural background from which our text may have originated. However, our (primary) understanding of texts does not depend on their historical backgrounds (and even less on our knowledge of their authors or specific authorial intentions), but on the way we and other readers before us - read, read and re-read the texts. In this regard, it seems to be fruitful as well as pragmatic to approach a text like the Posthomerica from different angles, to look at its history of reception and - in case there is no positive evidence - to try to (re)construct the Erwartungshorizont (Jauß) ${ }^{39}$ of 'possible readers' at specific times. The latter approach might help to find out whether a text can be put in an affirmative or negative dialogue with the cultural background of the period it (presumably) emerged from.

In line with the suggested 'open' dating of the Posthomerica as having been written at some point in the third century A.D. (cf. above, ch. 1.1.), the question arises as to whether or not the cultural background of the so-called 'Second Sophistic' might be the foil against which Quintus wrote his epic poem. ${ }^{40}$ An early dating to the first half of the third century A.D. would place the Posthomerica in the last decades of this period, which according to the majority of scholars comes to its end in the middle of the third century A.D., ${ }^{41}$ roughly coinciding with the death of Philostratus (c. 245 A.D.), the inventor of the term ( $\dot{\eta} \delta \varepsilon v-$ $\tau \varepsilon \rho \alpha \sigma o \varphi ı \tau \tau \kappa \eta ́, ~ V S ~ 481)$. As a consequence, a later dating of the Posthomerica towards the end of the third century A.D. at first sight seems to weaken this possible link between Quintus and the Second Sophistic. However, the chronological boundaries of the period itself are not fixed, and Philostratus himself opens room for an extension of the period back to Hellenistic times by starting his treatise not with sophists of the first century A.D., but with Aeschines, who lived in the fourth

39 On the term Erwartungshorizont cf. Jauß $\left({ }^{2} 1970\right)$.

40 Some aspects concerning Quintus and the Second Sophistic will be discussed and contextualised in a forthcoming article by S. Bär, "Quintus of Smyrna and the Second Sophistic".

41 Cf., e.g., Bowie (2002) 851, who proposes 60-230 A.D.; Swain (1996) 1-2 suggests 50-250 A.D., and Whitmarsh (2001a) 1 argues for "mid-first to the early third century of the common era". The main reasons for assuming the end around 250 A.D. are the lack of literary sources, the growing political instability of the Roman empire, and the shifting focus from Hellenism to Christianity; cf. Swain (1996) 3-7. 
century B.C. Likewise, the end of the Second Sophistic is subject to an ongoing scholarly debate, and some scholars tend to widen the scope of the period up until the fourth, fifth or even sixth century A.D. ${ }^{42}$ Thus, even a 'late' Quintus could have been influenced by (an extended) Second Sophistic, or - if we stick to an ending around 250 A.D. - at least by its literary aftermath.

The struggle for periodisation of the Second Sophistic is partly based on the differing emphases which scholars put on its main characteristics. Although Philostratus had introduced 'Second Sophistic' ( $\delta \varepsilon v \tau \varepsilon \rho \alpha \sigma o \varphi \imath \tau \imath \iota \eta ́)$ as a historical term referring to a specific declamatory rhetoric, the phrase has established itself in modern scholarship as a terminus technicus in a much wider sense: 'Second Sophistic' is nowadays defined as a cultural and political phenomenon aiming at the (literary) revitalisation of the (linguistic) norms and values of the classical period in order to give the 'Greeks under Rome' a new means of fictitious identification with their glorious past. ${ }^{43}$ In so doing, local elites and members of the well-educated upper class attempted to gain and / or preserve political power in the Roman empire by means of their classical erudition. On the basis of the established rhetorical education, an 'erudite' ( $\left.\pi \varepsilon \pi \alpha \_\delta \varepsilon v \mu \varepsilon \varepsilon^{\prime} \varsigma\right)$ was able to

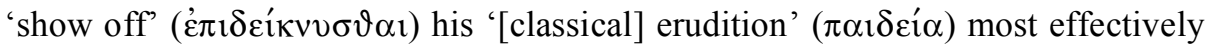
within the setting of a 'public [sophistic] performance' ( $\left.\varepsilon \pi i \delta \varepsilon \imath \xi_{1 \zeta}\right)$. Another professional way of displaying paideia was used by Greek philosophers, whose profession was politically supported by emperors like Marcus Aurelius and the foundation of well paid chairs in Athens. Philosophers embodied an idealised lifestyle which could be displayed in public appearances comparable to sophistic performances as well as privately within the different philosophical schools. ${ }^{44}$ A third way of displaying paideia can be found in the literary production by authors such as Lucian of Samosata. Having been highly educated and probably a successful sophist for a certain period of his life, Lucian displayed his paideia first and foremost within his literary, partly rhetorical ouvre. Texts like, for example, the True Stories (Verae historiae) operate with a wide knowledge of the Greek literary tradition and invite the well-educated readers to recognise the

42 The problem of periodisation is dicussed by Anderson (1989) 80-87. The widest timespan is given by Kennedy (1994) 230-256 who extends the boundaries up until the sixth century A.D. by strictly limiting his definition of 'Second Sophistic' to a purely rhetorical phenomenon.

43 Whitmarsh (2001a) 17-20 critically discusses restricted definitions of the Second Sophistic as a mere cultural phenomenon which is thought to have emerged primarily in opposition to the political dominance of the Romans. Rather - as Schmitz (1997) and others pointed out "Bildung und Macht" ("erudition and power') were two complementary factors in the struggle for (Greek) identity in this period. For further discussion of different aspects of the paideia concept see the various articles collected by Borg (2004).

44 Similarly, medical performances, such as public vivisections, were undertaken for 'epideictic' purposes; cf. von Staden (1995) and (1997). On medical matters in the Posthomerica, cf. the contribution of L. Ozbek in this volume. 
numerous literary allusions by means of their paideia. ${ }^{45}$ The political claims of the educated Greek elite were supported by emperors such as Trajan, Hadrian, or Marcus Aurelius who actively promoted Greek paideia and Roman Hellenisation. ${ }^{46}$ Thus, we can identify four main characteristics of the Second Sophistic, which shall be briefly summarised in order to show their possible relevance for Quintus' epic: (1) language, (2) rhetorical practice, (3) reception of classical themes, and (4) political power. ${ }^{47}$

(1) Language:

In the first place, 'Second Sophistic' is defined with regard to the linguistic and stylistic imitation of the Attic dialect of the the fifth and fourth century B.C. Since the late Hellenistic period, the Greek educational system had been focussing more and more on teaching Attic, both on the lower (grammatical) and on the higher (rhetorical) level of education, and in the Second Sophistic "atticizing language purism and atticizing rhetorical style [were] combined as a recognizable unit". ${ }^{48}$ A canon of classical texts, shaped by influential critics like Dionysius of Halicarnassus $\left(1^{\text {st }}\right.$ cent. B.C.), emerged from and centred around classical sophists and their Attic style. As a consequence, in literary production as well as in rhetorical performance of the Second Sophistic, a revival of 'Attic taste' can be observed.

(2) Rhetorical practice:

Rhetoric was not only a key element of education at schools where various forms of rhetorical exercises were practised, but became more and more important as a public means of expressing paideia, of shaping popular opinion and gaining political influence. So called Konzert- or Schauredner travelled around the Greek speaking world, displayed their erudition and brought classical themes back on stage. In performing epideictic rhetoric, ${ }^{49}$ the educated elite (re)presented itself in public by combining 'classicising' rhetoric and Atticism to a 'code', i.e. a shared system of reference and communication which was fully understandable only to the likes of them, to the (comparatively) small group of the $\pi \varepsilon \pi \alpha 1 \delta \varepsilon v \mu \varepsilon$ 'vot.

(3) Reception of classical themes:

Being linguistically and stylistically educated on the basis of classical texts meant being confronted with classical Greek themes from mythology and history, with rhetorical, philosophical or moral concepts as well as with political and social debates, which originally referred to a different (now historical) past and community. Being read time and again, the contents of the texts became more familiar and helped to shape the cultural identity of their recipients along classical lines.

45 Cf. von Möllendorff (2000a) 10-22.

46 Cf. Fein (1994).

47 Cf. the categorisation set up by Whitmarsh (2005).

48 Swain (1996) 25.

49 On the performative aspects of sophistic epideixis, cf. Korenjak (2000). 
Having lost power and political freedom, the Greek elite as well as their audience found a means of intellectually going back to their glorious past, of 'being Greek under Rome'. ${ }^{50}$ In terms of literary or rhetorical production, a sophist as well as any $\pi \varepsilon \pi \alpha 1 \delta \varepsilon v \mu \varepsilon \dot{v} v \varsigma$ was expected to dwell upon the topics, motives and genres established in and inherited from the classical period and to reproduce them mimetically and in constant variation.

(4) Political power:

Successful sophists such as Favorinus or Herodes Atticus were able to obtain influential positions at the imperial court; we hear of sophists who became ambassadors (e.g. Lucian), and find an increasing number of inscriptions in this period honouring sophists for a number of reasons in different poleis. ${ }^{51}$ Paideia as a result of rhetorical education had become a powerful means for the Greek speaking elite to define and establish itself further in Roman society. Sophists had an immense influence on the public opinion by their public lectures; the competitiveness in sophistic epideixis mirrors the struggle for political influence.

If we ask ourselves whether Quintus' epic fits into these categories or to what extent it may have been influenced by them, the following observations can be made:

(1) Language:

As a poetic text which is largely based on the Homeric Kunstsprache, the Posthomerica does not fulfill the linguistic and stylistic criteria developed for Second Sophistic prose in imitation of Attic authors. However, neither the fact that Quintus wrote an epic poem nor his usage of (pseudo-)Homeric language rules out a possible link between the Posthomerica and Second Sophistic literature fundamentally. Not only did many sophists write poetry, and poetry have an important place "in the cultural universe of the sophists", 52 but the linguistic status of Homer in the search for (pure) Atticism was also much debated. ${ }^{53}$ Although Homer was linguistically "a particular danger to the atticists", ${ }^{4}$ his epics remained the most important texts in the educational curriculum and were

50 Cf. the title of Goldhill (2001).

51 On the importance of epigraphical evidence for our understanding of the Second Sophistic see Schmitz (1997) passim, and esp., e.g., 101-110, and 136-146.

52 Bowie (1989) 209.

53 Cf., e.g., Aristid. Or. 1.328, claiming that the 'Homeric dialect' was a derivative of the Attic dialect (and, notably enough, not the other way round) - an assertion which is "to say the least tendentious, at worst transparently false" (Anderson [1993] 87).

54 Swain (1996) 55, who shortly summarises the various attempts to incorporate Homer into the canon of Attic writers (55-56): for example, Telephos of Pergamon regarded Homer as 'the purest writer of Greek' (cf. the title of one of his works [Suda s.v. = FGrHist 505]: ö $\tau$ нóvos o

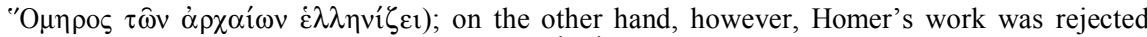
from the canon by the grammarian Moeris $\left(2^{\text {nd }} / 3^{\text {rd }}\right.$ cent. A.D. $)$ because of his chronological position as a "proto-Attic author" (Swain [1996] 56, with n. 54). 
frequently alluded to in intertextual references made by sophists in their rhetorical writings as well as in their declamatory performances. ${ }^{55}$ Thus, Homer's work remained a highly important and a continuous direct or indirect Referenztext for sophists in order to develop themes, to discuss cultural concepts and even to display their stylistic and linguistic brilliance by the aid of Homeric quotations or allusions. As a cultural phenomenon, the Second Sophistic cannot be thought of without Homer; thus, an author like Quintus who deliberately adopts the Homeric style and thematically fills in the gap between Iliad and Odyssey could have attempted to establish a third 'Homeric' Referenztext for Second Sophistic rhetorical practice. ${ }^{56}$ Seen from this angle, it is striking that the only indication of a sophist writing epic poetry in this period is Scopelianus, who wrote a Gigantias at the very beginning of the Second Sophistic (if we follow Philostratus' chronology), i.e. approximately 100 A.D. Bowie tries to explain the phenomenon that "our one example of sophistic epic dates from early in Philostratus' Second Sophistic" by arguing that "the demands (...) of successful declamation may not have been so obvious to Scopelianus as to a sophist a century later". ${ }^{57}$ However, telling the story the other way round, we could as well speculate whether Quintus, who may well have been a sophist himself, might have written his epic towards the 'end' of the Second Sophistic precisely for the opposite reasons: the demands of successful rhetoric had changed from declamation and prose to a new form of rhetorical poetry in the Homeric tradition. In this context, we could perhaps even situate Quintus' 'son' Dorotheos and his visio afresh (cf. above, ch. 1.1.): on the one hand, Christian writers of those days were trying hard to make themselves heard by inscribing themselves into the existing and established literary canon; on the other hand, as this literary canon was of a pagan nature, they were at pains not to submit themselves to their pagan 'forefathers' too strongly, but to come to terms with the fact that they were virtually unable to communicate their contents without the 'vessel' of the established pagan canon. ${ }^{58}$ Seen from this angle, a text like the Posthomerica looks perfectly suitable for this very purpose: being Homeric (or, rather, 'Homerising'), it is of canonical value beyond doubt; however, it is unhomeric enough insofar as it obviously 'corrects' some ethical problems of the Homeric poems by substituting abstract concepts such as 'fate'

55 See North (1952) and Bowie (1989) 210-212, who summarises various studies of quotations from archaic and classical poetry in Second Sophistic literature.

56 On the notion of Quintus as a Homerus novus cf. the contribution of S. Bär in this volume. Cf. also T. Schmitz's contribution on Quintus' technique of linking his epic to the Iliad and the Odyssey by means of ana- and prolepses.

57 Bowie (1989) 256.

58 Cf., e.g., Cameron (1999) 2: "The past was so real that it was the subject of intense competition. For Eusebius of Caesarea [...] and for other Christian writers, it had above all to be wrested from the grip of pagans." Cf. also, e.g., Brown (1971) 70-95. 
( $\mu$ oî $\rho, \alpha \hat{i} \sigma \alpha$, etc.) for the traditional Olympian gods to a large extent, as well as by incorporating some elements of Stoicism which, as is generally known, often served as a point of contact between early Christianity and established pagan

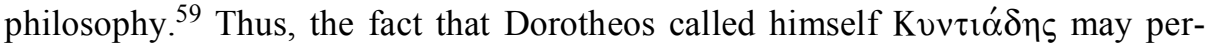
haps be interpreted as an attempt of a Christian writer who was looking for a point of contact with a suitable, yet 'morally acceptable' pagan work of literature to inscribe himself into Quintus' 'traditionalist school' which followed a strongly Homerising / archaising style of epic, but which was 'morally purified' as compared to Homer.

(2) Rhetorical practice:

With regard to the aspect of declamatory performance, the Posthomerica not only embeds itself in the established tradition of reading Homer as a literary text, but also evokes the original practice of performing epic poetry in various places by professional rhapsodes (oral poetry). ${ }^{60}$ Likewise, the Posthomerica can be envisioned as performed by a sophist on stage in the third century A.D. ${ }^{61}$ In addition to this, Quintus not only imitates Homer by including different kinds of speeches in his fictitious course of events, but he also seems to reflect the declamatory practice of his own time. A good example of this can be found in the rhetorical contest between Odysseus and Ajax over Achilles' armour: like two sophists competing on stage with speeches $\left(\mu \varepsilon \lambda \varepsilon^{\prime} \tau \alpha \imath\right)$ about the same topic, the two heroes use their rhetorical skills in order to persuade the audience of their individual claims. At least one of them - Odysseus - defines himself and appears as a $\pi \varepsilon \pi \alpha 1 \delta \varepsilon v \mu \varepsilon v \nu \varsigma$ by using the ecphrasis of Achilles' shield (Q.S. 5.6-101) as some kind of linguistic 'code' to be 'decoded' by his audience/ readership. ${ }^{62}$ The importance of ecphraseis, which developed as a genre of its own during the Second Sophistic (cf., e.g., Philostratus' Eikones, or Lucians Imagines and Panthea), and their prominent place in the Posthomerica contribute to the rhetorical colour of the epic. By using ecphrasis "as a means of both instruction and display", ${ }^{63}$ Quintus seems to follow a distinctively Second Sophistic tradition.

59 On the Posthomerica as an ethical 'corrective' to the Homeric poems, cf. Wenglinsky (1999) and (2002). Furthermore, cf. Gärtner (this volume) for the importance of the personifications of fate in the Posthomerica; Boyten (ibid.) for the notion of Neoptolemos as a 'morally purified' novus Achilles; Maciver (ibid.) for Stoic influence and the construction of new ethic values.

60 A phenomenological comparison between the performance practice of the Homeric rhapsodes of the seventh and sixth centuries B.C. and the sophists of the imperial period is offered by Korenjak (2003).

61 Cf. Appel (1994c) 9-13, however unduly speculative in his biographic approach.

62 Cf. the contribution of M. Baumbach in this volume.

63 Zeitlin (2001) 211. 
(3) Reception of classical themes:

The omnipresence of Homeric themes in the visual world ${ }^{64}$ as well as in the literature and the sophistic performances during the Second Sophistic clearly shows the ongoing interest in Homer and the importance of the Iliad and Odyssey for the educated elite as well as the broader audience / readership. In declamatory performances, a sophist often had to respond spontaneously to themes put forward by his audience; therefore it seems very likely that Homeric topics, which were at least vaguely familiar to many listeners, were frequently asked for. In focussing almost entirely on 'Homeric' (or, rather, 'Cyclic') themes and the crucial events of Troy's downfall, the Posthomerica could have perfectly met the ongoing interest in Homer which prose texts of the Second Sophistic also display. Furthermore, Quintus is not merely rewriting a Homeric story or filling a gap between these two epic poems, but he is competing with Homer in many ways; cf. the unhomeric opening of the Posthomerica without a proem, or the new version of the famous Homeric ecphrasis of the shield of Achilles. This literary $\alpha \gamma \omega \dot{v}$ ('competition') with Homer can be found in many Second Sophistic texts, in which Homer is sometimes criticised as a liar (Lucian, True Stories 1.1$)^{65}$ or corrected in detail (cf. in particular Dion of Prusa's Troikos [Or. 11], and Philostratus' Heroikos). Finally, with regard to the focus on the military side of the Trojan War, one could speculate whether Quintus intended to provide his readers with a new reference text about another great triumph in Greek military history: as "[b]oth for Greek citizens of the classical era, and for the Greeks of the continuing literary tradition, military activity is integral to any definition of masculinity and citizenship", ${ }^{66}$ and events of historical military success, especially over the Persians, are frequently alluded to in Second Sophistic declamations, the Trojan War and especially the sack of Troy could also be seen as a mythological prefiguration of the historical Persian Wars (i.e. the pattern 'victory of the Greeks over the [Asiatic] barbarians'). Seen from this angle, it seems plausible that the Posthomerica may have been perceived as a reference text of Greek selfdefinition from a political point of view too.

(4) Political power:

In this regard, no direct link between Quintus and the tradition of the Second Sophistic can be established for lack of external evidence about the contemporary reception of the Posthomerica. Even if we assume that Quintus himself was a sophist, we have no clue how a poetic work like his may have been judged by other members of the elite and what impact this could have had on political

64 Cf. Zeitlin (2001) 195-218.

65 On the notion of Homer as a liar, which is a typical feature of the Second Sophistic, and on Quintus 'correcting' this picture, see the forthcoming article by S. Bär (cf. our n. 40).

66 Goldhill (2001) 7. 
careers. The observation that Greek sophists frequently wrote poetry is one thing, the link between this kind of poetry and the struggle for political power another.

To summarise, we can conclude that the observations made are not clear enough to fully prove a link between Quintus and the Second Sophistic. However, there is no reason to generally question such a possible link either. As a consequence, we are entitled to put Quintus' epic in dialogue with the Second Sophistic and to contextualise the Posthomerica within the cultural and literary tendencies which were well established in that period.

\section{The Reception of the Posthomerica}

\subsection{Transmission, Rediscovery, and Renaissance Reception ${ }^{67}$}

As outlined above (ch. 1.1.), Quintus' Posthomerica fulfilled a public need for an epic poem to cover the gap between the Iliad and the Odyssey. Accordingly, his text must have been widely read, if not - at certain times - publicly recited. However, with the exception of the fact that Nonnos knew and responded to the Posthomerica, we know virtually nothing specific about the contemporary or late Antique reception and audience of Quintus' epic poem. Apart from the two references in the visio Dorothei which might point to our poet (cf. above, ch. 1.1.), we have no other nominatim reference to him in Antiquity. Then, in the Byzantine period, he is first mentioned by name several times by Eustathius of Thessalonica (1110-1198) ${ }^{68}$ as well as by John Tzetzes (1110-1180), who makes use of the Posthomerica in his own hexametric renarration of the Trojan War and occasionally refers to Quintus as his source. ${ }^{69}$ Therefore, these scholars must have been in possession of (or have had access to) now-lost manuscripts of the Posthomerica in the eastern empire. Furthermore, in one scholium of the Geneva manuscript (13 ${ }^{\text {th }}$ cent. A.D.), Quintus is once referred to explicitly as Köïv

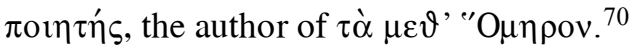

67 We would like to thank Dr A. Carvounis for her kind permission to make use of relevant information from her unpublished doctoral thesis for this chapter.

68 Cf. Vian (1963) VII n. 1 and James / Lee (2000) 3 n. 14 for the exact passages.

69 Cf. Vian (1963) VII n. 1+2 and James / Lee (2000) 4 n. 15 for the exact passages. Tzetzes was also, according to the present state of our knowledge, the first to call Quintus $\delta$ L $\mu v \rho v \alpha i o s$, probably following the allegedly autobiographical passage in Q.S. 12.310; cf. Vian loc.cit. n. 2.

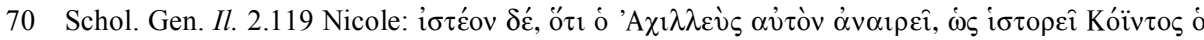

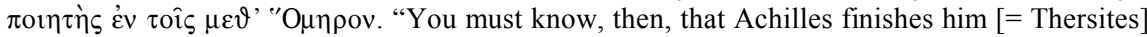
off, as Quintus reports in his Posthomerica." This remark is followed by a summary of how, according to Quintus, Achilles kills Penthesilea, falls in love with her too late, is mocked by Thersites, and kills him in the heat of the moment. 
The text of the Posthomerica as such came down to us ${ }^{71}$ in some twenty manuscripts of which three put it between the Homeric epics ${ }^{72}$ - a fact which indicates that the main reason for its transmission through the Middle Ages was probably not its literary quality, but its usefulness as a repository of the postIliadic stories. There are two now lost prototypes - a Subarchetypus $(\mathrm{Y})$ and a Hydruntinus $(\mathrm{H})-$, dated to the $14^{\text {th }}$ century and derived from an Archetypus $(\Omega)$ which is, most probably, datable to the $14^{\text {th }}$ (maybe $13^{\text {th }}$ ) century as well and lost too. Two of the extant codices - a Parrhasianus (P) and an incomplete Monacensis (M) - stem from Y, whereas all the others have their source in H. It was this second prototype that the Byzantine scholar and cardinal Basilius Bessarion (1403-1472) discovered in the monastery of San Niccolò di Casoli (near Otranto, Apulia) at some point between 1453 and 1462. Thus, the revival of our poet was initiated: a number of hand-written copies - the derivatives of $\mathrm{H}$ - were produced. One of these was made by the emigrant Byzantine scholar and philologist Constantine Lascaris (1434-1501) in $1496,^{73}$ accompanied by a preface in which he not only recounts the circumstances of Bessarion's discovery, but also reflects on Quintus' name, date, and provenance. Lascaris clearly recognised that Quintus

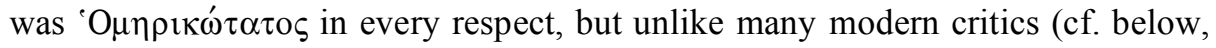
ch. 2.3.), he did not mean this as a criticism, but rather stated that Quintus "was a very good poet and aimed to imitate Homer on a large scale by taking over everything from him, (...) which makes him look like a perfect poet". ${ }^{74}$ According to the Renaissance's aim to reanimate yet surpass the cultural achievements of Antiquity, the fact that Quintus was a 'perfect' imitator of Homer was not despised as a token of his being a second-rate epigone, but, on the contrary, his ability to stand up to the quality of the likewise 'perfect poet-father' was rather highly praised and admired. ${ }^{75}$ Furthermore, we may also mention the Italian humanist and poet Angelo Poliziano (1454-1494) who, in his commentary on

71 The following remarks on the transmission of the text and its rediscovery and early (Renaissance) reception draw largely on James / Lee (2000) 1-4. On the history of the manuscript tradition, cf. the unprecedented work by Vian (1959b), summed up by $i d$. (1963) XLV-LV.

72 Vindobonensis Phil. gr. 5 (R); Cantabrigiensis, Coll. Corp. Christi 81 (C); Marcianus gr. Z 456 (V); cf. James / Lee (2000) 1 with n. 3.

73 Matritensis gr. $4686(=q)$. On Lascaris' edition, undertaken by himself and some of his pupils, cf. Vian (1959b) 32-38.

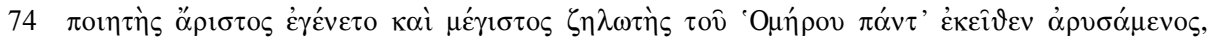

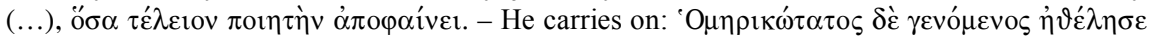

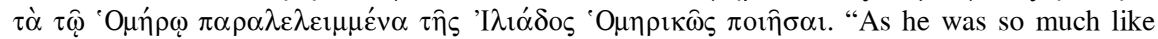
Homer, he wanted to do in a Homer-like way what had been left over by Homer from the Iliad." - Lascaris' text is fully reprinted by Köchly (1850) proleg. CXI-CXII (quotation accordingly).

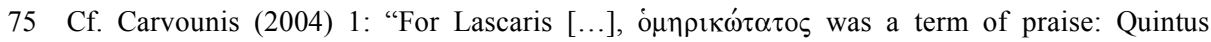
imitated Homer and got it right." 
Statius' Silvae, quotes from the Posthomerica several times. ${ }^{76}$ However, more interesting than this is the fact that he apparently mixes up Homer and Quintus several times, ${ }^{77}$ which, puzzling though it is, can account for the fact that Quintus was seen in one line with Homer.

All in all, it becomes clear that in its early Renaissance reception, Quintus' epic poem was taken seriously as a true work of art. Therefore, it is certainly no coincidence that only a few years after Lascaris had taken his copy and written his introduction, the first printed edition was issued by Aldine press in $1505 .{ }^{78}$ Thus, the Posthomerica saw the light of day again at last.

\subsection{Synopsis of Scholarship ${ }^{79}$}

It was only one century after the editio princeps had been issued by Aldine Press that in 1604 the German poet and philologist Lorenz Rhodomann (1546-1606) produced the first critical edition of the Posthomerica, in which he disposed of a vast number of scribal errors which the text had undergone during its transmission through the Middle Ages (listed in an appendix containing his emendationes). It was accompanied by a praefatio ad lectorem and a Latin translation facing the Greek text; thus it can, in nuce, be seen as the starting point for modern scholarship on Quintus. Ten years later, Rhodomann's edition was put in print again, supplemented by critical notes (adnotamenta, i.e. mostly textual conjectures) by Claude Dausque (1566-1644). On the basis of this 'Rhodomann/Dausque', Johannes Cornelius de Pauw published his own edition in 1734, complemented

76 Cf. Vian (1997) 985-987.

77 Cf. Carvounis (2004) 2-3.

78 There Quintus is called Calaber due to the location of the manuscript found by Bessarion (Calabria being the ancient geographic denotation for the eastern part of southern Italy). Although Rhodomann, in the praefatio to his edition (1604), already stated clearly that this was not appropriate, Quintus was still occasionally referred to as Calaber up until the mid- $19^{\text {th }}$ century.

79 The following synopsis is not meant to be comprehensive. For previous Forschungsüberblicke and / or bibliographies, cf. esp. Köchly (1850) praef. V-VIII and proleg. CXIII-CXIV, Zimmermann (1889) III-VI, Keydell (1931) 60-80 and (1941) 9-11, Vian (1959a) 7-15 (comprehensive bibliography covering the years 1505-1958 in chronological order), Schmidt (1999) 139-143 (with a particular focus on literary reception), Gärtner (2005) 30-37 (specifically on Quintus and Virgil, on which cf. below). Cf. also the online bibliography on http://athena.leidenuniv.nl/ letteren/opleiding/klassieketalen/index.php3? $m=184 \& c=154$ (active as at 31.10.2007). Our bibliography at the end of this volume comprises most of the literature on Quintus published in the $19^{\text {th }}$ and $20^{\text {th }}$ century, and a selection of reviews. 
by numerous textual notes of his own. Later, though, de Pauw and Dausque were heavily criticised by Gottfried Hermann for their conjectural changes. ${ }^{80}$

The following century, then, saw a few substantial new editions by eminent classical scholars. ${ }^{81}$ The first was done by Thomas Christian Tychsen (1758$1834)$ in 1807. Unlike the previous editors, he did not simply rely on the text of the Aldine, which was based on one single manuscript, but he instead collated some eleven codices, thereby recognising that the manuscripts of the Posthomerica constituted two classes. ${ }^{82}$ On the other hand, he took too much to athetising, which was rightly criticised later on. ${ }^{83}$ In 1840 , then, Karl Lehrs (1802-1878) published a new edition with a facing Latin prose translation, but no critical apparatus. This was soon afterwards followed by two editions by Hermann Köchly (1815-1876), whose major contribution to the text consisted in a fresh collation of the codex Monacensis (M). The first (1850) was accompanied by comprehensive prolegomena and an extensive Latin commentary. The second (1853) included only the Greek texts, with some changes to the first edition. ${ }^{84}$ Finally, Albert Zimmermann was the first to take into account a complete collation of the codex Parrhasianus (P) for his edition which was published in 1891. ${ }^{85}$ However, it was only more than seventy years later that the first edition based on a complete collation of all the relevant manuscripts and free from $19^{\text {th }}$ century's 'conjectural overindulgence' was produced by Francis Vian. His Budé edition was released in three volumes $(1963 ; 1966 ; 1969)$ and is accompanied by a French prose translation, a comprehensive critical apparatus and a footnote / endnote commentary which, in contrast to Köchly's, is not confined to textual criticism, but which deals selectively with various textual and interpretative issues. In comparison to this, Giuseppe Pompella's bilingual Greek-Italian edition - released in three volumes $(1979 ; 1987 ; 1993)$ and reissued in one volume in 2002, with some changes, but without the Italian translation - is only a partial improvement. Pompella rightly disposes of some unnecessary conjectures which essentially go back to the $19^{\text {th }}$ century but which sometimes still feature in Vian's

80 Hermann (1840) 257: "Bekanntlich ist bereits in früherer Zeit Vieles durch die geschickte Hand des Laurentius Rhodomannus verbessert worden, wogegen Dausqueius und Pauw meistens durch ihre Conjecturen das Gegentheil bewirkt haben."

81 Cf. also the overview by Vian (1959b) 7-9.

82 This has become communis opinio; cf. Tychsen (1807) XCIX-CI, Köchly (1850) C-CII, Zimmermann (1891) XXVI-XXVII, Vian (1959b) 15. The latter states unequivocally (7): "Son travail est la contribution la plus importante à l'histoire des manuscrits de QS [...]"

83 Cf. Zimmermann (1889) 2: "Wenn man dieser Richtung folgen und sämtliche verdächtigen Stellen ausmerzen wollte, so würde das ganze Gedicht um etwa 100 Verse ärmer werden."

84 It should be mentioned that Hermann Köchly was "Ordinarius für Klassische Philologie" in Zurich from 1850 to 1864 .

85 He did not collate the Parrhasianus himself, however, but drew on the work by Treu (1875). 
edition too; however, due to its small apparatus and numerous misprints, it has not superseded Vian's edition as the reference text for scholarly purposes.

Regarding translations, Quintus' text had to wait - apart from Rhodomann's Latin translation and a translation by the Italian polyhistor Bernardino Baldi (1533-1617) into 'Etruscan verse', a form of vernacular Italian - until the beginning of the $19^{\text {th }}$ century. A French translation by René Tourlet in 1800 was followed by an Italian one by Paolo Tarenghi in 1809 and some partial German translations before the first and so far only complete German translation was released in 1866 by Johann Jakob Christian Donner. Nobody who has seen it, however, would regret that this second-rate imitation of Voss's hexameter style has never been reissued and will now, after almost a century and a half, be replaced by a modern German prose translation by Ursula Gärtner (forthcoming 2008). The first English translation, then, carried out by Arthur S. Way in blank verses, was released in 1913 and reprinted several times; it is, as M. P. Cuypers put it, "occasionally harder to follow than the accompanying Greek text", 86 whereas the prose translation by Frederick M. Combellack (1968) is better than its reputation. All of these, however, have been replaced by the recent translation into a readable English rhythmic prose by Alan W. James (2004). ${ }^{87}$ Translations of the text into other European languages include, first and foremost, Vian's relatively free French prose translation which accompanies his Budé edition of the 1960's (cf. above), then Pompella's Italian translation in his three-volume edition published between 1979 and 1993 (cf. above), and two Spanish translations by Inés Calero Secall (1991) and Francisco Antonio García Romero (1997) respectively.

The launch of several editions and translations from the beginning of the $19^{\text {th }}$ century onwards strongly connected with an increasing scholarly interest in the Posthomerica at that time. As outlined above, Tychsen was the first to collate the different manuscripts; in fact, his work can be considered the beginning of modern scholarship on Quintus' epic. ${ }^{88}$ During the whole of the $19^{\text {th }}$ century, scholars were mostly concerned with the discussion of textual problems and their (sometimes unnecessary, yet nevertheless stimulating) emendation. This is probably best reflected in Köchly's Latin commentary (1850; cf. above) which primarily deals with textual issues. As it is, however, the first and (apart from Vian's footnote / endnote commentary) only full scale commentary on the whole poem, upon closer inspection, it provides many pieces of information which even today prove useful for modern scholarly needs. Furthermore, the nineteenth-century preoccu-

86 Cuypers (2005a) in her review of James (2004).

87 Cf. the unanimously positive reviews by Cuypers (2005a), González-Rivas (2005), Hall (2005), Bär (2006), Byre (2006), and Carvounis (2006).

88 His 1807 edition is also preceded by an introductory commentatio of a good hundred pages. 
pation with textual issues resulted in a number of vivid discussions, in which figures such as Franz Spitzner, Hermann Bonitz, Karl Lehrs, Carl Ludwig Struve and his nephew Jacob Theodor Struve, and even Gottfried Hermann, ${ }^{89}$ took part between the 1830's and 1860's. Textual criticism also lay at the heart of Albert Zimmermann's research on Quintus, published between 1885 and 1913 (on his 1891 edition cf. above).

However, towards the fin de siècle the first monographs began to appear that were not solely dealing with textual matters. We mention Martin Winkler (1875), who considered Quintus' linguistic idiosyncrasies in comparison to Homer and Apollonios Rhodios; Frederick A. Paley who developed the unequivocally wrong, yet stimulating theory that Quintus' Posthomerica 'represented' the texts of the Epic Cycle and were therefore to be considered the sources of Virgil and other later poets $;{ }^{90}$ Karl August Eduard Niemeyer $(1883 ; 1884)$ on Quintus' similes; Franz Kehmptzow (1891) on mythographic sources (largely in critical contention with Köchly's prolegomena); and finally the thesis of George W. Paschal (1904), which aimed "to give a comprehensive outline of the present state of our knowledge of the Posthomerica", ${ }^{91}$ basically dealing with linguistic, stylistic and source-critical issues. The latter (Quellenforschung) also became the main focus of a number of articles in the first half of the $20^{\text {th }}$ century - authors we may mention by name include, amongst others, Angelo Taccone, Luigi Castiglioni, Samuel E. Bassett, and Angelo Raffaele Sodano. Further essays which dealt with other aspects comprise George W. Elderkin's monograph Aspects of the Speech in the Later Greek Epic (1906), in which Quintus is taken into full account, George E. Duckworth's lengthy article (1936) on foreshadowing and suspense in the Posthomerica, ${ }^{92}$ and Melvin W. Mansur's thesis on the treatment of Homeric characters by Quintus (1940).

One topic, however, came to predominate at that time: the question of Quintus' relation to Latin authors and, in particular, to Virgil's Aeneid. ${ }^{93}$ Heated

89 Hermann (1840): a review of Spitzner (1839) and Köchly (1838).

90 To the best of our knowledge, Paley's essay represents the first Anglo-Saxon piece of scholarship solely devoted to Quintus. On Paley's views about Quintus and Virgil see the contribution of A. W. James in this volume. We would like to thank Prof. Dr Christopher Collard (The Queen's College, Oxford) for providing us with information on Paley from his forthcoming book Tragedy, Euripides, and Euripideans.

91 Paschal (1904) 3.

92 On the same topic, cf. the contribution of T. A. Schmitz in this volume.

93 For a synopsis of scholarship on this topic, cf. Gärtner (2005) 30-37 and the contribution of A. W. James in this volume. The marked increase in this field of research was probably to a large extent due to Richard Heinze's epoch-making monograph Virgils epische Technik (first published in 1903; a reprint of the third edition [31915] was issued in 1995) which also dealt with Quintus (cf. Heinze [31915] 63-81, and A. W. James in this volume). 
discussions amongst several scholars ${ }^{94}$ finally developed into a 'quarrel' between Rudolf Keydell and Francis Vian, the two most eminent Quintus scholars of the $20^{\text {th }}$ century. The former strongly believed that Quintus had been directly and significantly influenced not only by Virgil, but also by other Latin poets such as Ovid, Seneca, or even Cicero. ${ }^{95}$ The latter, on the other hand, vigorously rejected any kind of direct influence and instead explained all similarities between Quintus and Latin poetry as in terms of common lost Hellenistic sources. ${ }^{96}$ However, it was not until recently that a re-examination of all the relevant passages in the Posthomerica was undertaken without prejudice: Ursula Gärtner (2005) was able to show that Virgilian influence seems plausible in many instances, but can hardly ever be fully proven. ${ }^{97}$

Whereas Keydell was to write the article for Paulys Realenzyklopädie der classischen Altertumswissenschaft (1963), Vian has remained the most important figure in scholarship on Quintus over the past five decades. Apart from his critical edition (cf. above) and a considerable number of articles, he published two books in 1959: one gives account of his unequaled work on the manuscripts (Histoire de la tradition manuscrite de Quintus de Smyrne), the other is the first monograph to deal comprehensively with the Posthomerica (Recherches sur les Posthomerica de Quintus de Smyrne). ${ }^{98}$ Furthermore, in 1984 he published, together with Élie Battegay, a Greek-French Lexique de Quintus de Smyrne. ${ }^{99}$ It was Vian's work, then, which greatly facilitated research and gave rise to a number of articles by different scholars in the 1970's and ultimately to the first full scale commentary by Malcolm Campbell on Posthomerica 12. ${ }^{100}$ However, Campbell's commentary

94 E.g., Becker (1913), Bassett (1925a), Castiglioni (1926), Knight (1932), Kleinknecht (1944).

95 Cf., e.g., Keydell (1949/50) 81: "Unter den griechischen Dichtern des späteren Altertums, bei denen sich Berührungen mit römischer Poesie finden, ist Quintus von Smyrna derjenige, der am deutlichsten Bekanntschaft mit lateinischer Literatur verrät. Daß er Vergils Aeneis gekannt und ausgiebig benutzt hat, steht fest. Aber auch Ovids Metamorphosen sind ihm bekannt gewesen. [...] Jedoch auf diese beiden Hauptwerke der römischen Poesie kann sich die lateinische Lektüre des Quintus nicht beschränkt haben." Cf. also id. (1954) and (1961).

96 Cf., e.g., Vian (1963) XXXIV: "Les correspondances entre les auteurs latins et Quintus s'expliquent [...] par des sources grecques communes, qui doivent être le plus souvent des œuvres hellénistiques [...] Assurément, on ne saurait affirmer que Quintus ignorait les Latins; mais, même si par endroit ces lectures ont laissé des traces, la mise en œuvre a été opérée avec des matériaux grecs [...]" Cf. also id. (1959) 95-101.

97 However, the question as to how Quintus interacts with Virgil in more general terms still needs to be solved. It has even been suggested that he may be deliberately avoiding and / or 'unscribing' the Aeneid by not taking it into account at the most crucial points and / or dealing with major scenes in a deliberately different way from that of Virgil; cf. Cuypers (2005b) 606-607.

98 Vian's Recherches were followed shortly afterwards by the monograph of Kakridis (1962), written in Modern Greek. For the most part, however, this is a running commentary on specific textual and interpretative issues.

99 The Greek-Latin Index in Quintum Smyrnaeum by Pompella (1981) is not so useful.

100 Campbell (1981) VII explicitly acknowledges his indebtedness to Vian. 
is, by and large, restricted to textual parallels and linguistic idiosyncracies, and contributes little to a deeper understanding of the text. It was only some twenty years later (2000) that another commentary was published, produced by Alan W. James and Kevin Lee, on Posthomerica 5. Its authors take into account almost every aspect of the text (although they sometimes display a somewhat unidimensional conception of intertextuality), and most notably, they provide the first modern introduction to Quintus' poem as a whole. ${ }^{101}$

Since the 1980s, an increased interest in various aspects of our text is also reflected in several articles. We mention, exempli gratia, Giuseppe Giangrande (1986) on Quintus' literary and linguistic techniques; Włodzimierz Appel (1994) with some useful "grundsätzliche Bemerkungen" on different aspects (but unduly conservative in his biographic attitudes); ${ }^{102}$ John Dillon (1995) with some interesting considerations on a possible intertextual relation between Quintus and the Neoplatonist Theordoros of Asine (but with an unsustainable dating of the Posthomerica to the $4^{\text {th }}$ cent. A.D. as a conclusion; cf. above, ch. 1.1.); Robert Schmiel (1986) and Paul Schubert (1996) on the composition of book 1; Peter Schenk (1997) and Ernst Günther Schmidt (1999) on the narrative structure of the entire poem. Furthermore, there have been a number of Spanish publications by Francisco Antonio García Romero and Inés Calero Secall, mostly dealing with specific aspects which are relevant to the whole poem, the former in particular with intellectual concepts such as Stoicism, the latter predominantly with gender issues. Furthermore, Appel published two books: one is an analysis of book 4 (written in Polish), the other one (written in German) examines all the Homeric hapax legomena in the Posthomerica. Through this analysis, Appel was able to show that $10 \%$ of Quintus' complete vocabulary consist of Homeric hapax, but that Quintus uses most of these in a different semantic and / or grammatical context from Homer, which serves to demonstrate the poetic autonomy and creativity of our poet with regard to his Homeric model. ${ }^{103}$

Notwithstanding this significant increase in research interest during the 1990 's, the turn of the millennium can be seen, with only little exaggeration, as the actual turning point in Quintean scholarship. After the release of the commentary by James / Lee (2000; cf. above), there followed Pompella's edition (2002; cf. above); a helpful concordance by Manolis Papathomopoulos (2002) in two volumes; a reprint of Vian's Budé edition (2003); James' new English translation (2004; paperback 2007; cf. above) which includes a comprehensive introduction, critical summary, and a useful endnote commentary designed for a broader audi-

101 Cf. the reviews by Schmiel / Garstadt (2000), Whitby (2002), and Cuypers (2005b).

102 Appel (1994c).

103 Unfortunately, both of Appel's books have received very little attention - the first one because it is written in Polish, the second because it is barely accessible and obviously out of print. 
ence; ${ }^{104}$ and finally, Gärtner's monograph on Quintus and Virgil (2005; cf. above). Further publications are to be expected soon - apart from Gärtner's translation into German (forthcoming 2008; cf. above), there are a full scale commentary on Posthomerica 14 by Aikaterini Carvounis (forthcoming 2008), and commentaries in progress on book 10 (Georgios P. Tsomis) and on parts of book 1 (Silvio Bär) and 9 (Leyla Ozbek) respectively, as well as a monograph on the representation of heroes and heroism (Bellini Boyten), on the role of light, darkness and colours (Andrei Goția), and a study of the dynamic of intertextuality in similes, gnomai and ecphraseis of the Posthomerica (Calum A. Maciver).

\subsection{Verdicts and their Impacts}

However, a synopsis of scholarship on Quintus Smyrnaeus cannot end without the addition of a survey of all the negative judgments from which our poet has suffered in the past. To begin with, it has almost become a locus classicus within the community of contemporary late epic scholars to quote Hugh Lloyd-Jones' devastating verdict about Quintus in his review of Combellack's translation: "Among the late Greek epic poets Quintus is by far the worst. Nonnus, tasteless and turgid beyond measure as he is throughout the immense length of the Dionysiaca and the Paraphrase, has a ghastly vitality that carries the reader - or at least some readers - along with him. But the anaemic pastiche served up by Quintus is utterly devoid of life; even the Oenone episode in the tenth book is good only by comparison with what surrounds it." 105 Admittedly, we should not take this too much to heart, did it not represent but the tip of the iceberg - so much so that in 1999, Ernst Günther Schmidt entitled his overview article on scholarship and reception of the Posthomerica with the rhetorical question "Quintus von Smyrna - der schlechteste Dichter des Altertums?". For this is indeed the impression one may get when reading through some secondary literature. More than often, it is suggested that Quintus is an author who shows 'lack of imagination' and whose 'style is determined by deficiency in linguistic creativity', ${ }^{106}$ who

104 James' endnote commentary is heavily indebted to Vian's footnote / endnote commentary.

105 Lloyd-Jones (1969) 101, in his review of Combellack (1968). He passes into a criticism of Combellack's prose style and concludes that "it is not much more distasteful than the original".

106 Keydell (1963) 1293: "Mangel an Phantasie verraten auch die eigenen Erfindungen, die [...] nur in gewissen Grenzen ein Streben nach Variierung erkennen lassen [...]”; ibid. 1295: “〈Der Stil〉 wird aber vor allem durch den Mangel an sprachlicher Gestaltungskraft bestimmt, der den Dichter zwingt, in kurzem Abstand das eben gebrauchte Wort zu wiederholen, und ihn immer wieder dieselben Epitheta verwenden läßt, so sehr er sich auch in gewissem Umfange um Variation bemüht. Der Ausdruck ist matt, ohne Fülle und Leben." 
is simply 'monotonous', ${ }^{107}$ and who 'has achieved neither the monumentality and directness of Homeric poetry nor the psychological profundity of the epic narrative' 108 - and for whom, finally, the old art of epic poetry is 'long ago dead and buried'. ${ }^{109}$ The great Milman Parry, then, looking at Quintus from his very specific angle, claimed that "there is little to observe in this author except the misunderstanding of the nature of ornament", but that "Quintus does, however, do us a real service in helping us appreciate the real merit of Apollonios". ${ }^{110}$ Finally, even Vian not only joined this club of grumblers, but even went so far as to maintain that the poem's 'poverty of inspiration, frostiness of narration, and monotony of style' were due to 'a deficiency of the author's personality'. ${ }^{111}$ It will, therefore, come as no surprise that such a starting point has not necessarily facilitated and promoted research on Quintus and his poem on a more objective level (cf. below, ch. 3.).

However, strikingly enough, it seems that this negative attitude is, by and large, a phenomenon of the $20^{\text {th }}$ century, whereas in former times the Posthomerica was much more appreciated. During the the Renaissance, Quintus was

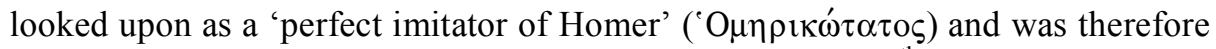
admired for his ability to achieve this 'perfection'. In the $19^{\text {th }}$ century, he was, as a rule, either ignored ${ }^{112}$ or appreciated. For the latter, one may, for example, quote Gottfried Hermann who declared firmly that 'Quintus' epic poem is the best after Homer's'. ${ }^{113}$ Furthermore, Frederick Paley expressed his unorthodox view that "if the Posthomerica of Quintus had come down to us as an original poem with the traditional authority of our Homer, and the Iliad and Odyssey had been called [...] "posthomeric," the position of the poems, as far as language and matter are concerned, would have been reversed; or at least the superior merits of the Iliad, if acknowledged, would have been attributed to its later develop-

107 Fornaro (2001) 724: “[D]ie Bemühung, das Vorbild zu variieren und Monotonie zu vermeiden, ist nicht immer gelungen."

108 Dihle (1989) 436: "Die Monumentalität und Unmittelbarkeit der homerischen Dichtung erreichte er ebensowenig wie die psychologische Vertiefung des epischen Berichtes [...]"

109 Lesky (1957/58) 739: "Für Dichtung dieser Art ist das alte Epos längst tot und begraben [...]" Notably enough, however, he lessened his acrimonious tone in the second and third edition of his Geschichte der griechischen Literatur to "[f]ür Dichtung dieser Art gehört der Reichtum der alten Epik längst der Vergangenheit an" (Lesky $\left.\left[{ }^{2} 1963\right] 871=\left[{ }^{3} 1971\right] 912\right)$.

110 Parry (1971) 429 (i.e. originally in his MA thesis 1923).

111 Vian (1959a) 250: "Le lecteur des Posthomerica est de prime abord déçu par la pauvreté de l'inspiration, par la froideur du récit et la monotonie du style: ces défauts trahissent un manque certain de personnalité chez l'auteur [...]"

112 On the ignorance of the Posthomerica where acquaintance might be expected see Schmidt (1999) $139-141$.

113 Hermann (1840) 257: "Quintus von Smyrna gehört zu den am wenigsten gelesenen Schriftstellern, obgleich sein Gedicht unter den uns noch übrigen epischen Gedichten der Griechen nach Homer das beste ist." 
ment". ${ }^{114}$ However, it is not through scholarship, but by the aid of a particular piece of literature that Quintus' poem has had (and in fact continues to enjoy) a significant impact in popular reception, at least as far as the German-speaking part of Europe is concerned. For Gustav Schwab (1792-1850), in his Schönste Sagen des klassischen Altertums, used the Posthomerica as his main source for the renarration of the events between the Iliad and the Odyssey, and in the preface to the second volume of his mythological textbook, we learn that he appreciated Quintus not only as a welcome repository of the post-Iliadic stories, but also for his poetic abilites. ${ }^{115}$ As a result, Schwab keeps relatively close to Quintus' narrative and sometimes even includes material which is, from a strictly narratological point of view, superfluous, such as, for example, the pair of women's speeches in Q.S. 1.403-476. Thus, indirectly, the Posthomerica has had a lasting effect on many generations of pupils (and also on others) who through Schwab's lens read (and appreciated?) this 'monotonous' author who is so 'utterly devoid of life'.

\section{Perspectives and New Approaches}

The idea of organising an international conference on Quintus Smyrnaeus' Posthomerica emerged from the discrepancy between the comparatively meagre (scholarly) reception of this late epic poem on the one hand (cf. above, ch. 2.2.) and the prospering studies in the field of Second Sophistic literature on the other. Could scholarship on Quintus benefit from the results gained by exploring the Second Sophistic? Would a closer link of the Posthomerica to the Second Sophistic open new horizons for the evaluation of the end of this period? And which 'Quintean' means of transforming Homer can be found in other literary works of this period?

Questions like these lead to the invitation of 18 scholars on Quintus from different countries and with various academic backgrounds. Established scholars as well as Nachwuchswissenschaftler both in the field of the Second Sophistic and that of the Posthomerica were invited to discuss traditional views and new perspectives and methods of approach in scholarship on the Posthomerica. In this

$\overline{114 \text { Paley (1876) } 7 .}$

115 Cf. Schwab (1839) (quoted after the reprint edition [1986] 336): “[...] ist hier der Darsteller [i.e. Schwab] so glücklich gewesen, in der Fortsetzung Homers durch den Dichter Quintus [...] eine echt poetische Grundlage und Stoff wie Form zu fortlaufender Erzählung vorzufinden. Die Paralipomenen dieses Poeten sind ein klassisches Kunstwerk und werden hoffentlich in ihrer Schönheit und Größe, gleich den Schöpfungen anderer Dichter, durch die treffliche metrische Übersetzung des Herrn Professors Platz [...] sich bald die Anerkennung aller Freunde echter Poesie gewinnen." (The translation by Platz has, to the best of our knowledge, never been fully issued.) 
regard, the discussion was not limited to the relation between Quintus and the Second Sophistic, but we instead hoped to combine new readings of Quintus' epic with aspects of its historical and literary contextualisation in the third century A.D. The result was an intense discussion of a broad spectrum of topics, ranging from analysing the usage and literary history of different motives and epic elements, to evaluating specific techniques of composition and historical backgrounds as well as possible modes of reception. Although not all papers were (and are) primarily concerned with the question of a possible link between the Posthomerica and the Second Sophistic, the results of all contributions can help to better understand the epic in negation or affirmation of such a possible literary and cultural embedding.

We decided to present the contributions to this volume in four sections:

1) The Epic Art of the Posthomerica: Poetics and Narrative Structure;

2) Quintus and his (Homeric) Models: Imitation and Innovation;

3) Cosmology, Ethics, and Heroism;

4) Quintus, the Second Sophistic and the Imperial Period.

Of course not all papers fit perfectly into the categories to which they have been assigned - some tackle overlapping topics, others deal with very specific aspects, which might well have deserved a category of their own -, but the structure broadly reflects the main fields of discussion at the conference.

In order to reflect the international character of the conference as well as the methodological and thematic variety of the papers presented, all participants were invited to publish in their native language. The result is a book whose basic language is English, containing sixteen contributions, of which ten are in English, five in German, and one in Italian. English abstracts of all contributions are provided in an appendix, and two indices will help readers with specific interests to approach and use the book for their purposes.

The bibliography at the end contains not only all works cited in the individual contributions, but also comprises most literature on Quintus published in the $19^{\text {th }}$ and $20^{\text {th }}$ century, as well as a selection of reviews. May our readers thus be inspired to read and carry on further research on the Posthomerica and explore the

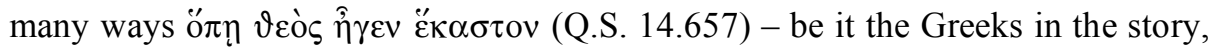
the historical or the future readers of the Posthomerica. 